\title{
Social Networks and the Choice of Market Outlets among Aquafarmers in Kenya
}

\author{
Jack Odhiambo Malit ${ }^{1}$, Mary W. K. Mathenge1, Augustus Muluvi ${ }^{2}$ \\ ${ }^{1}$ Department of Agricultural Economics and Agribusiness Management, Egerton University, Egerton, Kenya \\ ${ }^{2}$ Department of Economics, Egerton University, Egerton, Kenya \\ Email: jackmalit1@gmail.com, mathengemk@gmail.com, sammuluvi@yahoo.com
}

How to cite this paper: Malit, J.O., Mathenge, M.W.K. and Muluvi, A. (2021) Social Networks and the Choice of Market Outlets among Aquafarmers in Kenya. Open Access Library Journal, 8: e8133.

https://doi.org/10.4236/oalib.1108133

Received: October 29, 2021

Accepted: December 5, 2021

Published: December 8, 2021

Copyright () 2021 by author(s) and Open Access Library Inc.

This work is licensed under the Creative Commons Attribution International License (CC BY 4.0).

http://creativecommons.org/licenses/by/4.0/

(c) (i) Open Access

\begin{abstract}
Capture fisheries and aquafarming contribute to improve income and nutrition among producers and consumers of fish, respectively. With the global fluctuation in capture fisheries, attention has been diverted towards aquafarming which has shown an increasing trend in the recent years. Despite this growing trend, the average per capita fish consumption in Kenya is still far below the recommended level. In response, several efforts have been initiated by the government of Kenya towards promoting aquafarming to increase fish production. However, fish marketing has remained unaddressed over the years in Kenya. Social networks play a key role in facilitating marketing through group formation and networking. This paper attempts to analyze fish marketing by determining the effects of social networks on the choice of market outlets among aquafarmers. The paper used primary data which was collected in Nyeri, Siaya, Kiambu, Kirinyaga and Kakamega Counties using semi structured questionnaires on a sample of 300 fish farmers. A multivariate probit model was used in analyzing the effect of social networks on market outlet choices. Fish farmers mainly sold to retailers, consumers, collectors and wholesalers. Results indicated that the number of farmer groups, membership to Farm Africa, number of years in a group and linkages with the fish market affected the choice of market outlets. The paper recommends the need to reduce bureaucracies in group registration as a way of enhancing the benefits that accrue from group marketing. In addition, the paper underscores the importance of extension service, increased training and provision of credit facilities to farmers to enhance fish marketing.
\end{abstract}

\section{Subject Areas}

Economics 


\section{Keywords}

Aquaculture, Capture Fishing, Market Outlet, Social Networks

\section{Introduction}

Capture fisheries and aquafarming contribute to high incomes and improved nutrition among producers and consumers of fish, respectively [1] [2]. They supply 17 percent of animal proteins globally, which are important in the human diet and support livelihood of about 12 percent of the world total population [3]. Cai and Leung [4] indicated that the global capture fisheries has been declining over the years from 92.2 million tons in 2011 to 89.6 million tons in 2016. This resulted from increased fishing due to high population growth, unemployment, open access to fisheries and use of destructive fishing gears which affected the stock of fish [1]. On the other hand, the global aquaculture production has been rising over the years at the rate of 8.2 percent per annum in the last three decades and forms a large proportion of fish currently consumed by humans [5].

In Africa, the average fish consumption is estimated to be $8.9 \mathrm{~kg}$ per capita, which is below the world average of about $20 \mathrm{Kg}$ per capita [3]. This means that the region will therefore need 2.49 million tons of fish to meet the total fish demand of 31 million tons by the year 2050 [6]. In the year 2017, the value of fish and fish products which Africa imported was 3.7 percent of the global fish imports [7].

In Kenya, capture fisheries and aquaculture sector contribute about 0.8 percent to the national Gross Domestic Product (GDP), employ about 500,000 people directly and support the livelihood of about two million people indirectly [8]. Fish consumption in Kenya has been decreasing from an average of $6 \mathrm{Kg}$ per capita in 2011 to $4.0 \mathrm{Kg}$ in 2018 [9]. This is as a result of high prices and the dwindling stock of fish. In 2017, the total fish consumption in Kenya was estimated at around 188,000 MT [8]. Capture fisheries on the other hand has declined, probably due to the anthropogenic activities along the water bodies. Overall the country faces a deficit of 39,700 MT in consumption which can be met through aquafarming and fish imports. Despite the deficit, the Ministry of Agriculture is pursuing a comprehensive plan to increase the national per capita fish consumption from $4.0 \mathrm{Kg}$ per year to $10.0 \mathrm{Kg}$ as part of the ongoing nutrition campaign in boosting the immunity against corona virus [10].

The declining fish production in Kenya is probably due to reduced interventions by the Kenyan government in promoting aquaculture. However, the trend in production is different in various parts of the country. There are high aquaculture activities in Bungoma, Busia, Kakamega, Meru, Kisii, Kisumu, Nyeri, Murang'a and Embu Counties compared to others like Lamu, Elgeyo Marakwet and Kitui Counties where aquaculture is on the decline (State Department of Fisheries, 2016). To enhance aquaculture, the government has established the Kenya 
Marine and Fisheries Research Institute to pursue aquaculture research so as to increase food security, employment and hatching of fingerlings for fish production [11].

Much of the efforts by the government of Kenya have largely focused on the production side with less emphasis on marketing. Fish marketing plays a key role in meeting the goals of food security, sustainable agriculture as well as in alleviating poverty. Smallholder farmers have had challenges in penetrating markets, due to challenges from market liberalization. As a result, only few farmers sell to formal markets since they practice subsistence production [12]. Aquafarmers have continued to experience challenges in selling fish from their farms due to inadequate investment in the market, including storage facilities and preservation methods [13]. However, with adequate investment in the market, through storage facilities and preservation methods, there are high chances of farmers selling fish in market while still fresh thereby attracting high prices [2] [13]. Furthermore, organizing aquafarmers to access and actively participate in the market remain a big challenge facing fish marketing [14]. Because fish is highly perishable product, most aquafarmers have challenges accessing formal market outlets and as a result they rely on middlemen who offer relatively lower prices impacting negatively to farmers' household welfare.

Social networks play an important role in facilitating fish marketing through group formation. Studies have indicated that fish marketing has not been well organized, hence there is need for developing networks that will facilitate access to fish market [15]. According to Kamau et al. [16], social networks through group formation have the potential of increasing the bargaining power of aquafarmers hence reducing barriers to entry in any potential market. In addition, it helps to reduce transaction and information costs in decision making and on market outlets respectively [17] [18]. This paper therefore explores the roles of social networks in enhancing fish marketing among aquafarmers with the view of improving their potential and welfare. The paper is based on secondary data collected from 300 aquafarms in selected counties in Kenya namely Kakamega, Siaya, Kiambu, Kirinyaga and Nyeri Counties. These counties are selected because they have favorable climatic conditions for aquaculture and offer a large market for fish. The social networks considered in the study area include: number of groups that the aquafarmer belongs, extension contacts, commercial contacts with fish buyers, membership to Farm Africa and the number of years one is a member of aqua-related group.

\section{Literature Review}

Social network is considered as important mechanism in spreading information and technology [19]. Social networks promote technology adoption and awareness among smallholder farmers. However, the strengths of these social networks vary by technology. A social network is defined as individual, agents, or groups with strong relationship with one another [20]. According to study by 
Muange et al. [20] social networks measures include information from village administrators and extension officers. The study established that social networks are more with farmers with more direct contacts with extension officers.

The analysis of social networks assumes that relationships are important. It maps and measures both formal and informal relationships that are necessary in understanding factors which facilitates and impedes knowledge flow [21]. Social capital is a glue that is used to hold society as one, without it there is no human well-being and economic growth. According to Cote and Healy [22] emphasis has been placed on the role of networks as well as civil norms in various definitions. Studies indicate that social network is found on personal relationships maintained by the households influencing production decisions, economic outcomes and the marketing outlet decisions [15] [16]. Ofuoku et al. [23] among others, point to the importance to markets, membership to marketing organizations, assets ownership, risk attitudes, transaction cost, access to information and agricultural extension services as the main determinants of the choice of the marketing outlets.

Kawala et al. [24] did a study on the determinants of fish market channels in Busia, Kenya. The study established that belonging to the fish traders' associations increases the likelihood of a farmer to choose a formal trade. This implied that farmers that belonged to marketing groups had high chances of selling to a formal trade channel, a decision which is considered to be rational. Farmers are encouraged to form their own organizations where they are in a position to promote formal trade. This is attributed to their uniform voice for bargaining for fair taxes and policies that would favor them. Sigei et al. [17] mentioned that farmers that belonged to a marketing group were influenced to sell in urban markets while those who were not belonging to a group marketed in local market or even at farm gate.

Turner and Stead [25] did a study on the influence of social networks on the fisher's behavior in Northumberland, England. Quantitative social network analysis was used to compare the structure of information sharing networks. The results established that different networks were used in sharing information. In addition, fishers reported to share information with networks displaying different levels of cohesiveness. It was established that the ability to accept the agricultural extension services, the size of the person's network size and the structural position of an individual within a network influence information sharing and hence market access.

Odetola et al. [15] did a study on fish farming commercialization in Lagos State in Nigeria. The study showed the importance of cooperative societies in serving poor farmers in rural areas which could not be served well by formal institutions such as commercial banks and other government owned financial institutions. The formal institutions do not provide loan to the rural farmers since the farmers do not comply with bureaucratic procedures and the costs of services associated with lending. The study recommended the farmers should join the 
cooperative societies so as to facilitate fish commercialization.

Studies by Honja et al. [26] point to the importance of social networks in enhancing marketing of fish. Some of social networks identified include community self-help groups in rural areas, fish traders' associations, cooperative societies among others. The literature points to the importance of social networks in facilitating commercialization of fish by making it easy to acquire high breeds of the fingerlings, easy access to market and reduction of transaction costs. Farmers that belong to marketing groups have high chances of selling to a formal trade channel and making of rational decisions. In addition, social networks help to reduce risks present in the market as well provide assistance to the farmers by providing access to storage facilities, transport, information and better terms of trade through creation of better relationships with the actors that are present in the various marketing chains. The studies establish that belonging to the fish traders' associations increases the likelihood of a farmer to choose a formal trade.

\section{Theoretical Model}

The analytical framework used in this study is based on Random Utility theory in quantifying preferences where farmers choose a particular method from a set of alternatives. The aqua farmer is faced with multiple alternatives on where to sell fish. The attractiveness of any one market outlet within the choice set is dependent on several factors including financial performance and access to a particular market outlet. It holds the assumption that the farmer would choose a technique that yield the highest utility from alternative techniques available. Greene [27] indicate that random utility method can be used in modeling the behavior of a farmer whose decision is generated based on utility maximization. This implies that alternative choice on market outlet has different private costs and benefits, hence a different utility, to the aquafarmer. The farmer will choose market outlet provided that the expected utility he gets from it exceeds expected utility from other market outlets as shown.

$$
\begin{aligned}
& Y^{*}=Y_{i}, \text { if } V_{i}>V_{j} \\
& Y^{*}=Y_{j}, \text { if } V_{i} \leq V_{j}
\end{aligned}
$$

$Y_{i}$ represent the market outlet $i$ while $Y_{j}$ is an alternative market outlet $j . V_{i}$ and $V_{j}$ are expected indirect utility values for market outlets $i$ and $j$ respectively. $Y^{*}$ represent the market outlet that is actually chosen. The utility function is assumed to be known by each aquafarmer even though some of its components are unobserved. The unobserved part of the utility is considered as random variable. The expected indirect utility is modelled as the sum of the observed variables and the non-observable random part.

$$
V_{i}=\beta^{1} i X_{i}+\varepsilon_{i}
$$

The choice utility of implementing an alternative market outlet can be written as; 


$$
V_{j}=\beta^{1} j X_{j}+\varepsilon_{j}
$$

$\beta^{1} i$ and $\beta^{1} j$ are vectors of the parameters. The farmers can thus decide simultaneously whether to choose one or more market outlet conditional on the vectors of the explanatory variables $X_{i}$ and $X_{j}$. A multivariate probit model can thus be used to analyze the farmer's joint decisions on choosing a market outlet. From Equations (3) and (4), the specification of multivariate probit model therefore takes the form:

$$
Y_{i j}^{*}=B_{i k} X_{i k}+\varepsilon_{i}\left(K=Y_{1}, Y_{2}, Y_{n}\right)
$$

where $j=1,2,3$ and 4 are the market outlet choices while $B_{i k}$ represent the vector of the parameters that shows the impact of changes of the independent variables, $X_{i k}$ is the vector of independent variables and $\varepsilon_{i}$ represents the random error. $K$ shows the utility levels that are obtained from different market outlet choices.

$$
\begin{gathered}
Y_{i}=1 \text { if } Y_{i}^{*}>0 \\
Y_{i}=0 \text { if } Y_{i}^{*}<0
\end{gathered}
$$

$Y_{i}^{*}$ is the unobserved latent variable showing the probability of choosing a given market outlet.

\section{Methodology}

\subsection{Study Area}

This study was conducted in selected counties in Kenya namely Kakamega, Siaya, Kiambu, Kirinyaga and Nyeri Counties (Figure 1). These Counties were found to have favorable climatic conditions for aquaculture, offer a large market for fish and have a high population of potential fish consumers. Further, they are part of the counties where Farm Africa implemented aquaculture programs. The study relied on the data collected under the 3R (Resilient, Robust, Reliable) Kenya project by Egerton University in the five counties. The aim of the $3 R$ program is to assess lessons and evidence from Food and Nutrition security programs such as Kenya Market-Led Aquaculture Program (K-MAP) that support both competitive and market-oriented agriculture [28].

Nyeri County experience annual rainfall ranges between $1200 \mathrm{~mm}-1600 \mathrm{~mm}$ during long rains and between $500 \mathrm{~mm}-1500 \mathrm{~mm}$ during short rains [29]. The temperature and rainfall patterns are favorable for aquaculture related activities in the county. Siaya county was found suitable for the study since it borders Lake Victoria hence suitable for aquafarming practices. Kiambu county was selected because it borders Nairobi county which is a metropolitan area and is a potential fish market. While Kirinyaga County was chosen since it has six major rivers that are suitable for aquaculture production since they support aquaculture production. Lastly, Kakamega County is the third largely populated after Nairobi and Kiambu Counties hence it is a potential fish market. 


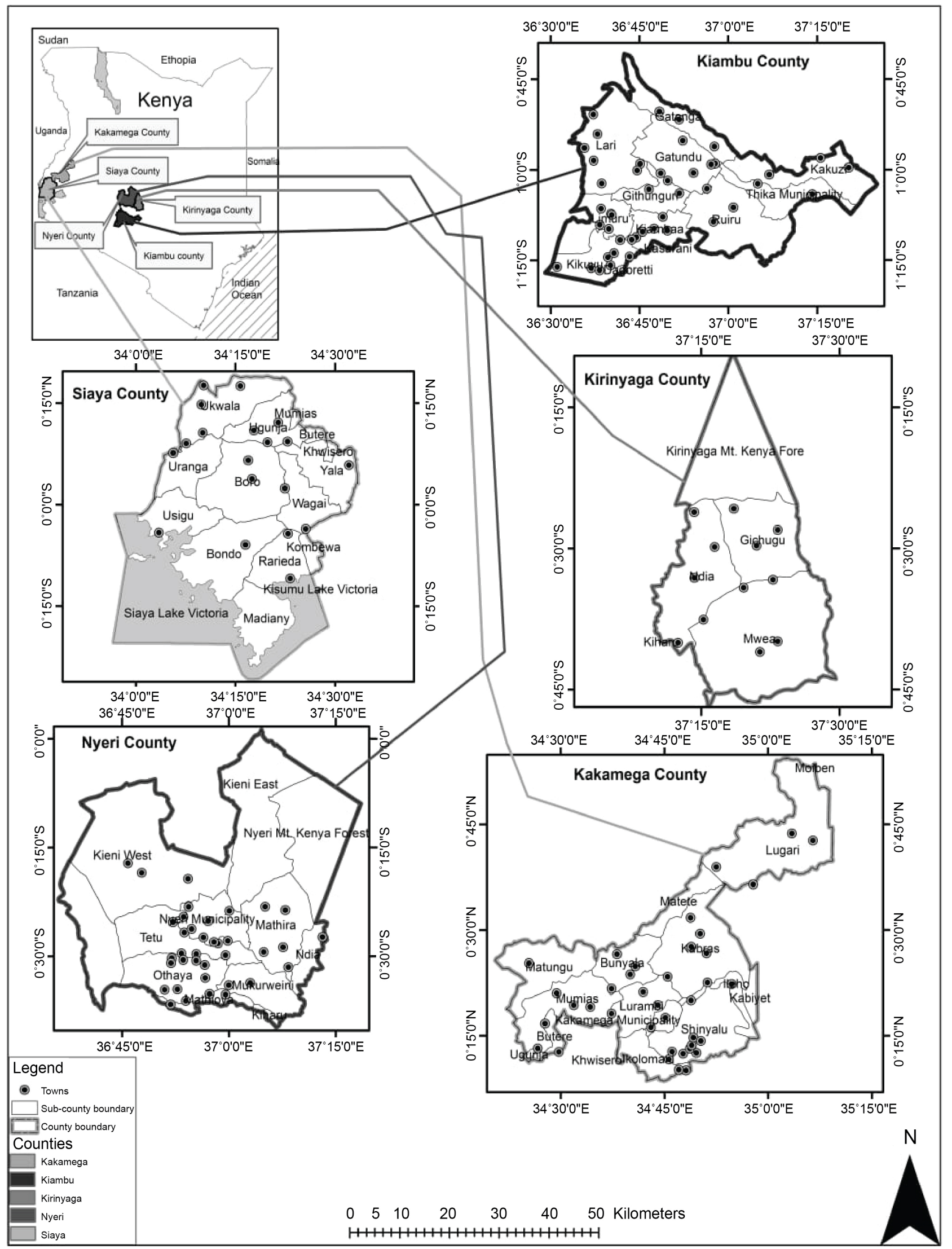

Figure 1. A map representing the study area. Source: World Resource Centre (2021). 


\subsection{Sampling Procedure and Sample Size}

The target population consisted of fish farmers that were producing and selling fish between September 2017 and August 2018. The study adopted a multistage sampling method so as to get the desired sample size. In the first stage, purposive sampling method was used to select Kirinyaga, Nyeri, Kakamega, Siaya and Kiambu counties. The second stage involved selecting sub counties with active aquafarming practices. Lastly, a systematic random sampling was used to select the households to be interviewed from available at the county.

The sample size for this study was determined using the formula given by Kothari [30] as illustrated in the equation:

$$
n=\frac{Z^{2} p q}{e^{2}}
$$

where $n$ is the sample size, $Z$ is the critical value (1.96) that is obtained at $5 \%$ significance level, $p$ is the proportion of population of interest (0.5). The proportion is set at 0.5 in order to get a reliable and sufficient estimate while $q$ is the weighting variable given by $1-p$ and $e$ is the acceptable error. According to Kothari [30] an error of less than 10 percent is acceptable thus this study used an error of 0.0566 which is precise providing a smaller sample size that could fit the budget for the study.

$$
n=\frac{1.96^{2} 0.5 * 0.5}{0.0566^{2}}=299.79
$$

This was estimated to get a sample size of 300 fish farmers. The study considered households that produced and sold fish in the last one year.

\subsection{Empirical Model}

Farmers can choose more than one market outlet hence multivariate probit (MVP) model was considered to be appropriate in the analysis. MVP allows for the possible correlation in decision to participate in more than two market outlets. It holds the assumption that there is correlation and interdependence in the aquafarmers' choice on the market outlets. Since there is a possibility that information on the group membership affect the fish farmers' probability of selecting a given market outlet, univariate logit or probit cannot be used since it assumes that the error terms are distributed independently hence ignoring the correlations amongst the outcomes thus lead to inefficient parameter estimates [31]. Ignoring the correlations when analyzing the simultaneous choice on the market outlets lead to biased and incorrect estimates of the standard errors. A multivariate probit model thus can be used to analyze the farmer's joint decisions on choosing a market outlet. The specification of multivariate probit model would therefore take the form:

$$
\begin{aligned}
Y_{i j}^{*} & =\alpha_{0}+\alpha_{1} \text { Farmorg }+\alpha_{2} \text { Hhsize }+\alpha_{3} f_{\text {gender }}+\alpha_{4} f_{\text {edu }}+\alpha_{5} \text { Age }+\alpha_{6} \text { Altincome } \\
& +\alpha_{7} \text { Experince }+\alpha_{8} \text { Quantity }+\alpha_{9} \text { landsize aqua }+\alpha_{10} \text { Preservation } \\
& +\alpha_{11} \text { Distance }+\alpha_{12} \text { Linkfhmkt }+\alpha_{13} \text { Acccredit }+\alpha_{14} \text { Extension contact } \\
& +\alpha_{15} \text { Farmafri }+\alpha_{16} \text { contact } \_ \text {fish }+\alpha_{17} \text { farmorg } \_ \text {year }+\varepsilon_{i}
\end{aligned}
$$


$Y_{i j}^{*}$ is the unobserved latent variable showing the probability of choosing a given market outlet, $\alpha_{i}$ is the vector of parameters and $\varepsilon_{i}$ is the random error term. The error terms in the different market outlet choices are assumed to be correlated. The error terms follow a multivariate normal distribution with a mean of zero and a variance covariance matrix $\varepsilon$ with a value of 1 in the leading diagonal. The multivariate probit normal distribution is $(0, \Omega)$ and the symmetric covariance matrix given as:

$$
\Omega=\begin{array}{ccc}
1 & p_{x} 1_{x} 2 & p_{x} 1_{x} n \\
p_{x} 2_{x} 1 & 1 & p_{x} 2_{x} n \\
p_{x} n_{x} 1 & p_{x} n_{x} 2 & 1
\end{array}
$$

The off-diagonal elements allow for correlation across the error terms of several latent equations which show the unobserved characteristics that affect the choice of the alternatives. Table 1 shows the variables, their description, measurements and the expected signs. The variables in Table 1 are used in deter-

\begin{tabular}{|c|c|c|c|}
\hline Variables & Description and Measurement of Variables & Measurement of variables & Expected Sign \\
\hline \multicolumn{4}{|l|}{ Dependent } \\
\hline$Y_{i j}^{*}$ & $\begin{array}{l}\text { Choice of market outlets (retailers, consumers, collectors } \\
\text { and wholesalers) }\end{array}$ & & \\
\hline \multicolumn{4}{|l|}{ Independent } \\
\hline Farmorg & Number of organizations aquafarmer belongs & Continuous & + \\
\hline Hhsize & Household size & Continuous & $+/-$ \\
\hline f_gender & Gender of the farmer & Dummy, $1=$ Male, $0=$ Male & $+1-$ \\
\hline f_edu & Years of education & Continuous & + \\
\hline Age & Age of the farmer & Continuous & $+/-$ \\
\hline Altincome & Income from other sources (Kenya Shillings) & Continuous & $+1-$ \\
\hline Experience & Experience in aquaculture in years & Continuous & + \\
\hline Quantity & $\begin{array}{l}\text { Quantity of fish produced (main type of fish produced) in } \\
\text { Kilograms }\end{array}$ & Continuous & + \\
\hline landsize aqua & Size of land under aquaculture in acres & Continuous & + \\
\hline Preservation & Access to fish preservation & Dummy, $1=$ Yes, $0=$ No & + \\
\hline Distance & Distance to the nearest market in Kilometres & Continuous & + \\
\hline Linkfhmkt & Access to linkages with the fish market & Dummy, $1=$ Yes, $0=$ No & + \\
\hline Acccredit & Access to credit & Dummy, $1=$ Yes, $0=$ No & + \\
\hline Extension contacts & Number of contacts with extension officers (per year) & Continuous & + \\
\hline Farmafri & Engagement with Farm Africa & (Dummy, $1=$ Yes, 0 = No) & + \\
\hline contact_fish & $\begin{array}{l}\text { Number of commercial contacts do you have with the fish } \\
\text { buyers (per year) }\end{array}$ & Continuous & + \\
\hline farmorg_year & $\begin{array}{l}\text { Maximum number of years one is a member of aqua-related } \\
\text { group }\end{array}$ & Continuous & + \\
\hline
\end{tabular}
mining the effect of social networks on the choice of market outlets.

Table 1. Variables used in Multivariate probit model.

Source: Author (2021). 


\section{Results and Discussion}

\subsection{Characterization of Fish Market Outlets}

There are various market outlets in the region, including, retailers, consumers, collectors and wholesalers. Fish farmers reported different percentages for the quantities of fish sold in the various market outlets. Table 2 indicates that majority of fish farmers (about 73\%) sold their fish directly to consumer market outlet while 35 percent, 16 percent and 17 percent of fish farmers sold to retailers, collectors and wholesaler's market outlets, respectively. Majority of farmers sold to retailers and consumer outlets since these outlets are accessible and they do not require any procedures to sell to. The results from this study is similar to results obtained by Nyaga et al. [12] that established that fish farmers sold about $49 \%, 29 \%$ and $22 \%$ of their fish to neighbors, direct market and traders, respectively.

Table 3 describes the prices and quantities of fish sold in the various market outlets. The price of fish was found to be high in collector market outlet with a mean price of Kenya Shillings 461.16 while the mean price was lowest in retailer market out at Kenya Shillings 328.15. In addition, the mean prices of fish in consumers and wholesalers market outlets were Kenya Shillings 338.77 and 415. 78, respectively. This implies that collectors and wholesaler market outlets were lucrative since it offers better prices as compared to other outlets. This is similar to the results found by Louw et al. [32] which found out that wholesaler market outlet offers best market outlet compared to other market outlets. The minimum and the maximum quantity of fish sold were $22 \mathrm{Kg}$ and $20050 \mathrm{Kg}$, respectively. Results established that fish farmers sold highest volume of fish to wholesaler market outlet at volume of 1748.71 , followed by collector, retailer and consumer market outlets at volumes of 1587.75, 1011.70 and 735.39 respectively. According to Timothy et al. [33], farmers that preferred wholesaler and collector market outlets have the advantage of selling fish in bulk.

Table 2. Description of fish market outlets.

\begin{tabular}{cccccccccc}
\hline & \multicolumn{9}{c}{ Fish marketing outlets } \\
\cline { 2 - 9 } Choice & \multicolumn{2}{c}{ Retailers } & \multicolumn{2}{c}{ Consumers } & \multicolumn{2}{c}{ Collectors } & \multicolumn{2}{c}{ Wholesalers } \\
\cline { 2 - 10 } & Frequency & $\%$ & Frequency & $\%$ & Frequency & $\%$ & Frequency & $\%$ \\
\hline Yes & 93 & 34.96 & 193 & 72.56 & 43 & 16.17 & 45 & 16.92 \\
No & 173 & 65.04 & 73 & 27.44 & 223 & 83.83 & 221 & 83.08 \\
\hline
\end{tabular}

Table 3. Prices of fish in fish market outlets.

\begin{tabular}{ccccccccc}
\hline \multirow{2}{*}{ Choice } & \multicolumn{7}{c}{ Fish marketing outlets } \\
\cline { 2 - 10 } & Metailers (93) & \multicolumn{2}{c}{ Consumers (193) } & \multicolumn{2}{c}{ Collectors (43) } & \multicolumn{2}{c}{ Wholesalers (45) } \\
\cline { 2 - 10 } & Std.dev & Mean & Std.dev & Mean & Std.dev & Mean & Std. dev \\
\hline Price & 328.15 & 112.62 & 338.77 & 108.53 & 461.16 & 319.89 & 415.78 & 141.40 \\
Quantity sold & 1011.70 & 1504.00 & 735.39 & 1813.91 & 1587.75 & 3361.48 & 1748.71 & 3966.09 \\
\hline
\end{tabular}




\subsection{Household Characteristics by Market Outlets}

The mean age of aquafarmers that were interviewed was 52 years. The average household size was 5.7 persons which was higher than the average household size of 3.9 persons [9]. This implies that majority of farmers had large household size that would provide cheap labor that would enhance market participation in most of the lucrative market outlets. The mean years of education was 12 years, this indicates that majority of the fish farmers were literate farmers hence had acquired skills and technical knowhow in aquafarming.

The average distance to the market was 21.64 Kilometers. This shows that majority of the fish farmers were far from the market hence they had to incur transportation costs in accessing best market outlets. Results indicated that the average year of experience in aquafarming was 6.76. This is a clear indication that most aquafarmers were experienced in aquafarming hence they can be able to forecast market situations and get better prices for their fish. The average land size under aquaculture was $1123.70 \mathrm{Km}$, the large land size implies high fish output hence farmers are more likely to sell in market outlets that purchase large quantities of fish at higher prices. The average number of extension contacts in a year was 1.27. The lower number of extension contacts indicate that most of the farmers have inadequate training on various markets.

Results in Table 4 indicated that the average number of commercial contacts with the fish buyers were 16.39. This high number of commercial contacts with the fish buyers implies that farmers had already established specific outlets where they sell their fish. The mean number of groups for farmers was 2.82, and indication that most of the farmers belonged to more than one group. Furthermore, these can take advantage of these groups, by selling to a particular market outlet hence bargaining for better prices. The mean number of years in groups was found to be 2.82 which is enough years for farmers to adjust their marketing

Table 4. Description of continuous data.

\begin{tabular}{|c|c|c|c|c|}
\hline Variables & Means & Standard deviation & Minimum & Maximum \\
\hline Age (Years) & 52.02 & 14.06 & 21 & 92 \\
\hline Household size & 5.67 & 2.93 & 1 & 20 \\
\hline Years of education & 12.02 & 3.49 & 0 & 16 \\
\hline Distance to the market (kilometres) & 21.64 & 76.06 & 0 & 700 \\
\hline Experience in Aquafarming (years) & 6.76 & 6.68 & 1 & 44 \\
\hline Land size under Aquaculture (acres) & 1123.70 & 2478.39 & 0 & 20000 \\
\hline Number of extension contacts & 1.27 & 4.16 & 0 & 36 \\
\hline Number of commercial contacts & 16.39 & 49.19 & 0 & 600 \\
\hline Number of groups & 2.82 & 1.51 & 0 & 6 \\
\hline Number of years in groups & 2.78 & 3.83 & 0 & 31 \\
\hline Off-farm income (Kenya shillings) & 439173.2 & 709795.7 & 0 & 6000000 \\
\hline
\end{tabular}

Number of observations $=266$. 
linking. Results showed that the mean off-farm income was 439,917.2. the large amount of off farm implies that farmers had adequate resources that can assist in complying with other bureaucracies in profitable market outlets.

Results indicated that male farmers doing aquafarming were $86.09 \%$ while female aquafarmers were $13.91 \%$. A plausible reason for this was that male farmers have access to resources in acquiring ponds, cages and tanks. Results indicated that only $36.47 \%$ of farmers were members of Farm Africa, these farmers benefit from networks of aqua shops in disseminating quality equipment and inputs as well promoting the adoption of aquaculture best practices for improved fish production. Farmers who had access to preservation facilities were $59.02 \%$, an indication that most fish produced by farmers would end spoiled before sale. The findings revealed that $18.42 \%$ of farmers had linkages with the fish market. This is an indication that few farmers had established fish market. Results indicated that only $53.38 \%$ of the farmers had access to credit, an indication that there were farmers who still did not have the capacity to purchase inputs for production.

\subsection{Effects of Social Networks on Fish Market Outlets}

Social network in this case considered the number of groups that the aquafarmers is a member, extension contacts, commercial contacts with fish buyers, membership to Farm Africa and the number of years one is a member of aquarelated group. However, household characteristics were also included in the model.

Multivariate probit model was estimated jointly for four binary dependent variables, including retailers, consumers, collectors and wholesalers market outlets. The Wald Chi2 test $\left(X^{2}(266)=360.41, \mathrm{p}=0.0000\right)$ is significant at 1 percent level implying that the subsets of the coefficients of the model is jointly significant. The number of observations was different from 300 due to non-response by some households. Furthermore, the Wald Chi2 test indicates that the explanatory power of the factors that are included in the model is satisfactory. The multivariate probit model fit the data well, similarly, the model is significant since the null hypothesis that the choice of the four market outlets is independent was rejected at $1 \%$ significant level. The likelihood ratio test in the model $(\operatorname{chi} 2(6)=$ $39.8795)$ prob $>$ Chi $2=0.0000$ ) is significant, indicating that there is independence between fish market choice decision $($ rho21 $=$ rho31 $=$ rho41 $=$ rho32 $=$ rho42 $=$ rho43 $=0$ ), hence there is significant joint correlations for the estimated coefficients across the equations. The off-diagonal elements of the covariance matrix are significant, indicating that there are unobserved heterogeneities that influence the decision to participate in different fish market outlets. Similarly, the correlation coefficients in the error terms are significant, hence the decision to choose one market outlet affect the decision to choose another market outlet.

Based on the results of multivariate probit model in Table 5, most of the variables were significant in more than one market outlet. Results indicate that out 
Table 5. Variables on multivariate probit model.

\begin{tabular}{|c|c|c|c|c|c|c|c|c|}
\hline \multirow[b]{2}{*}{ Variables } & \multicolumn{2}{|c|}{ Retailers } & \multicolumn{2}{|c|}{ Consumers } & \multicolumn{2}{|c|}{ Collectors } & \multicolumn{2}{|c|}{ Wholesalers } \\
\hline & Coeff & Std. Err. & Coeff & Std.Err. & Coeff & Std. Err. & Coeff & Std.Err. \\
\hline gender & $-0.589^{\star *}$ & 0.297 & 0.216 & 0.262 & -0.266 & 0.326 & 0.252 & 0.347 \\
\hline Household size & 0.020 & 0.032 & $0.067^{*}$ & 0.039 & -0.056 & 0.038 & $0.077^{\star *}$ & 0.032 \\
\hline Age & -0.009 & 0.007 & 0.012 & 0.008 & -0.005 & 0.008 & 0.003 & 0.008 \\
\hline Experience & -0.034 & 0.022 & -0.022 & 0.020 & $0.071^{\star \star *}$ & 0.022 & 0.029 & 0.021 \\
\hline Farmafrica & 0.001 & 0.197 & $0.574^{\star \star}$ & 0.239 & 0.033 & 0.222 & -0.299 & 0.200 \\
\hline logLandsize_aqua & $-0.132^{\star * *}$ & 0.039 & 0.044 & 0.038 & -0.040 & 0.042 & -0.012 & 0.046 \\
\hline Distance & 0.000 & 0.001 & 0.001 & 0.001 & 0.001 & 0.001 & $-0.003^{\star *}$ & 0.001 \\
\hline Extension contact & $0.084^{\star * *}$ & 0.022 & $-0.184^{\star \star \star}$ & 0.040 & $0.100^{\star * *}$ & 0.025 & 0.038 & 0.025 \\
\hline Commercial_cont & 0.002 & 0.002 & -0.001 & 0.002 & -0.000 & 0.002 & -0.000 & 0.002 \\
\hline Linkfhmkt & $-0.779^{* * *}$ & 0.294 & -0.218 & 0.265 & $0.757^{\star * *}$ & 0.257 & $0.491^{\star *}$ & 0.228 \\
\hline Log_Quantity & $0.162^{\star *}$ & 0.082 & $-0.137^{*}$ & 0.075 & $0.225^{\star *}$ & 0.087 & 0.112 & 0.095 \\
\hline f_edu & $-0.062^{\star *}$ & 0.028 & 0.001 & 0.032 & 0.016 & 0.036 & 0.036 & 0.032 \\
\hline Access to credit & 0.114 & 0.209 & $-0.359^{\star}$ & 0.215 & -0.048 & 0.224 & $0.509^{* *}$ & 0.224 \\
\hline Number of groups & $-0.277^{\star * \star}$ & 0.074 & -0.074 & 0.072 & $0.238^{\star * *}$ & 0.085 & $0.205^{\star * *}$ & 0.073 \\
\hline LogAltincome & 0.026 & 0.022 & -0.002 & 0.020 & -0.006 & 0.024 & 0.003 & 0.027 \\
\hline Preservation & -0.305 & 0.202 & 0.098 & 0.222 & -0.087 & 0.228 & $0.766^{* * *}$ & 0.237 \\
\hline Number of years in a group & -0.017 & 0.023 & $-0.062^{\star \star}$ & 0.029 & -0.023 & 0.026 & 0.033 & 0.020 \\
\hline _cons & $1.413^{*}$ & 0.759 & 1.258 & 0.782 & $-3.094^{* * *}$ & 0.935 & $-4.346^{* * *}$ & 0.978 \\
\hline
\end{tabular}

Number of observations $=266$. L.R test of $\operatorname{rho} 21=\operatorname{rho} 31=\operatorname{rho} 41=\operatorname{rho} 32=\operatorname{rho} 42=\operatorname{rho} 43=0$ chi2 $(6)=39.8795$ Prob $>$ Chi2 $=$ 0.0000. Wald Chi2 $(68)=360.41$, Log pseudo likelihood $=-350.76704$ Prob $>$ Chi2 $=0.0000 .{ }^{*},{ }^{* *}$ and ${ }^{* *}$ represents $1 \%, 5 \%$ and $10 \%$ significant levels, respectively.

of the explanatory variables employed, gender, household size, experience, membership to farm Africa, land size under aquaculture, distance to the market, number of extension contacts, linkages with fish market, quantity of fish produced, education level of the farmer, access to credit, number of organizations, access to fish preservation and the number of years a farmer has been a member of organization were found to be significant in the different market outlets.

In terms of gender, male aqua farmers were negatively significant in retailer market outlet at 5 percent significant level. A possible reason is that male farmers are risk takers hence they are able to search markets that are competitive and in distant places hence they will unlikely sell to retailers. In addition, the people with the tasks to control resources in most homesteads are male farmers hence they participate in day to day business decision making. In terms of gender, male farmers were less likely to sell to retailer market outlet. This is attributed to the fact that male farmers are tasked with responsibilities of controlling resources in most homesteads hence they participate in day to day business decision making. This finding is similar to the work by Sigei et al. [34] who estab- 
lished that male farmers are risk takers hence they are capable of searching for markets in distant places.

Household size was found to be positively and significantly influence the likelihood of choosing consumer and wholesaler market outlet at 10 and 5 percent significance level, respectively. Aqua farmers with large household size prefer selling to wholesaler outlet since large household size is assumed to have plenty labor force that is able to facilitate transportation of fish to the final market place. The results confirm the study carried out by Tewodros [35] that established that large family size has better labor endowment, which enables households to travel to reach wholesalers in the nearby markets.

Experience in fish farming was found to be positively significant in collector market outlet at 1 percent significant level. Experience in farming increases market participation through improved bargaining power in the market. Further, experience improves negotiation power of farmers in the market. Farmers with more experience in aquafarming prefer selling to collector market outlet due to the fact that experience helps aqua farmers to adjust their marketing link; hence they will probably choose collectors which offer lucrative price deals. This study concurs with the study done by Wosene et al. [36] which highlights that experienced farmers are more knowledgeable of cost and benefits that are associated with pepper marketing outlets; hence the farmers will prefer selling to lucrative market outlets.

Experience in fish farming was found to be positively significant in collector market outlet at 1 percent significant level. Experience in farming increases market participation through improved bargaining power in the market. Further, experience improves negotiation power of farmers in the market. Farmers with more experience in aquafarming prefer selling to collector market outlet due to the fact that experience helps aqua farmers to adjust their marketing link; hence they will probably choose collectors which offer lucrative price deals. This study concurs with the study done by Wosene et al. [36] which highlights that experienced farmers are more knowledgeable of cost and benefits that are associated with pepper marketing outlets; hence the farmers will prefer selling to lucrative market outlets.

Membership to Farm Africa is positively significant in consumer market outlet at 5 percent significant level. This is because Farm Africa implemented extension programs, where fish farmers were enlightened on selling to consumers which offered relatively better prices compared to retailers which do not offer better prices, Furthermore, since many members of Farm Africa were older farmers; they preferred selling to consumer market outlets other than other market outlets.

Land size under aquaculture was found to be negatively significant in retailer market outlet at 1 percent significant level. Land size under aquaculture negatively affected the likelihood of selling to retailer market outlet. This is attributed to the possibility that farmers with large land size produce more fish, hence 
would sell in other market outlets that afford to buy fish in large quantities and leave other market outlets such as retailer which buy fish in small quantities. The finding is similar to the results obtained by Abate et al. [37] who established that an increase in land size allotment by one unit increases by decreases the probability of selling to retailer market outlet.

Distance to the market negatively influences the likelihood of selling to wholesaler market outlet at 5 percent significant level. The negative sign implies that fish farmers living far away from the market are less likely to sell to wholesalers. In addition, the negative sign implies that longer distance to the nearest market translates to longer time taken to transport fish. Farmers that were far from fish market were unlikely to sell to wholesaler market outlet. Selling fish to wholesalers requires adequate transportation facilities as well as labor endowment necessary to reach wholesalers which increases the costs associated with marketing. In reality, most aqua farmers prefer selling fish in the nearest market since it reduces the time spent in transportation, saves on transport cost and reduces the chances of fish spoilage. Mburu et al. [38] established that the longer the distance to the market, the higher the transportation cost, hence higher cost of milk marketing. This finding is in line with the study done by Tarekegn et al. [39] that found out that with increase distance to the market, bee farmers preferred selling to nearby outlets that are not associated with higher transportation costs.

The number of extension contacts positively influenced the probability of selling to retailer and collector market outlet at 1 percent significance level and negatively influenced the probability of selling to consumer market outlet at 1 percent significance level. This may be due to the fact that farmers with many extension contacts may probably know about many market outlets which offer better prices for their produces like the case of collector market. Farmers that received more extension contacts were less likely to sell fish to consumer market outlets who buys fish in small quantities and at low prices and more likely to sell in other market outlets. Similar results were obtained by Wosene et al. [36] that established that extension service increases the chances of farmers to acquire important market information that will enable pepper producers in improving production method, thus lead to more output hence increases the probability of the farmer in choosing the best market outlet. The results affirm with the notion which implies that extension service acquired by the farmer on marketing increases the farmer's willingness to participate in lucrative marketing outlets [1].

Access to linkages with the fish market is important in fish marketing since it ensures that producers have steady market for their fish. It was found to be positively significant in collectors and wholesaler at 1 percent and 5 percent significant levels, respectively and negatively significant in retailer market outlet at 1 percent significant level. Fish farmers with linkages with fish market preferred selling in market outlets which offer better prices for their fish. This is concurring with results from this study in which wholesaler and collectors market outlets offered better prices for fish than retailer market outlet. This finding is simi- 
lar to the study by Awuor et al. [5] that found out that effective market linkage between aqua farmers and other stakeholders have benefits, including assured price and assured market.

Quantity of fish produced negatively influenced the likelihood of choosing consumer market outlet at 10 percent significance level. This implies that when the quantity of fish produced increases, farmers would avoid selling to consumer market outlet since this outlet demand small quantities of fish for consumption. Based on the quantities of fish produced, results indicate that farmers preferred selling to collector market outlet due to the ability of this market outlet to purchase large quantity of fish at fair price. At the same time, avoid selling to consumer market outlet since this outlet buy fish in small quantities. This implies that when the quantity of fish produced is large, farmers would prefer selling to market outlet that buys large volume of fish at fair price. This finding is similar to the work by Wosene et al. [36] which indicated that quantity of pepper produced positively affected lucrative market outlets.

Education level was determined by the number of years that aqua farmers have spent in school. Education level is negatively significant in retailer market outlet at 5 percent significant level. The negative relationship between education level and retailer market outlet implies that educated farmers make informed decisions on choosing the best marketing outlets; hence farmers would sell fish after considering the marketing margin as well as the marketing cost. This is similar to the study by Mburu et al. [38] which highlighted that education is considered as important indicator of social change, where it increases knowledge and skills useful in collecting and interpreting information necessary in making more productive and marketing decisions.

Access to credit was positively significant in wholesaler market outlet at 5 percent significant level and negatively significant in consumer market outlet at 10 percent significance level. Credit increases the capacity of production, thereby enhancing fish marketing among farmers. This implies that fish farmers who had access to credit were able to produce large volumes of fish, hence would sell to wholesaler market outlet, that mostly buy fish in large quantities. Farmers who did not access credit produced fish in small quantities, hence end up selling to consumer market outlet. The result is similar to the study done by Mmbando et al. [40] which indicated that access to credit increases the probability of maize producer to sell to traders in nearby market as well as wholesalers in nearby towns.

Number of farmer groups was found to be positively significant in collectors and wholesaler market outlets at 1 percent significant level. However, number of farmer groups was negatively significant in retailer market outlet at 1 percent. This is due to the fact that farmers with many farmer groups are likely to know about market outlet which offers better prices for the produce. Fish farmers with many groups are more likely to practice bulking; hence they are able to gain the advantage of economies of scale. This suggests that fish farmers with many 
groups will more likely to sell to wholesalers and collectors than retailers. Group membership promotes unity and sense of belonging in increasing the bargaining and negotiation for better trading terms, hence leading to reduced transaction costs. The results from this study is similar to the study by Nyaga et al. [12] which established that membership to groups is associated with the likelihood of farmer's selling to the traders' channel unlike neighbor's channel.

Access to preservation facilities is positively significant in wholesaler market outlet at 1 percent significant level. Preservation facilities positively influenced the chances of selling to wholesaler market outlet. This is attributed to the fact that preserved fish has high chances of staying longer before spoilage, hence farmers have adequate time to transport fish to wholesaler market outlet, which buys in bulk and offers better prices. This is in line with Wosene et al. [36] that found out that pepper preservation had a positive and significant relationship with wholesaler market outlet.

Number of years in a group was found to be negatively significant at consumer market outlet at 5 percent significance level. This is attributed to the fact that farmers with many years in a group are more knowledgeable on costs and benefits that are associated with fish marketing outlets. Farmers join groups for several reasons including, easy access to inputs, extension services, having collective sales and for social reasons. Experience in cooperative groups helps the farmers to adjust their marketing link, in search of other alternative outlets that offer better prices for fish [36]. This means that farmers with many years in a group were less likely to sell to consumers. This is similar to the study carried out by Jari and Fraser [41] that highlighted that farmers with many years of experience in groups have the ability of reaching distant places. In addition, experience in groups make farmers share information and broaden their social capital.

\section{Conclusions and Recommendation}

\subsection{Conclusions}

The study determined the effects of social networks on the choice of market outlets. These market outlets include retailers, consumers, collectors and wholesalers. Social network factors that explained the choice of market outlets include: number of farmer groups, membership to Farm Africa, number of years in a group and linkages with the fish market. Retailer market outlets were affected by linkages with the fish market and number of groups, while consumer market outlet was affected by membership to farm Africa and number of years in a group. On the other hand, linkages with the fish market and number of groups affected both collector and wholesaler market outlets.

Other factors that affected the choice of market outlets include gender, household size, experience in aquafarming, land size under aquaculture, distance to the market, number of extension contacts, quantity of fish produced, education level of the farmer, access to credit and access to preservation facilities. Results indicated that collector and wholesaler market outlets offered better prices for fish. 


\subsection{Recommendation}

The government and other entities need to ensure compulsory group membership in order to increase their bargaining power. Establishment of fish collecting centers in some of the potential areas encourages fish farmers to sell fish at a better price. Farmers who belong to groups usually market their fish collectively, hence giving them advantage of accessing market outlets which offer better prices for fish. Farmers need to create linkages with the fish market in ensuring that they get stable market for fish. This would ensure that farmers sell their fish to collector and wholesaler market outlets that offer better prices for fish. In addition, policy should include having many extension contacts, trainings and provision of credit to farmers in enhancing fish marketing. This would ensure that farmers have access to enough information on quality, quantity and prices of fish in the various market outlets.

\subsection{Further Research}

The study proposed to carry out the impact of farmer profitability under the different market outlets in fish value chain.

\section{Conflicts of Interest}

The authors declare no conflicts of interest.

\section{References}

[1] Otieno, D., Omiti, J., Nyanamba, T. and Mccullough, E. (2009) Market Participation by Vegetable farmers in Kenya: A Comparison of Rural and Peri-Urban Areas. African Journal of Agricultural Research, 4, 451-460.

[2] Golden, C.D., Seto, K.L., Dey, M.M., Chen, O.L., Gephart, A., Myers, S.S., Smith, M., Vaitla, B. and Allison, E.H. (2017) Does Aquaculture Support the Needs of Nutritionally Vulnerable Nations? Frontiers in Marine Science, 4, Article No. 159. https://doi.org/10.3389/fmars.2017.00159

[3] Food and Agriculture Organization (FAO) (2018) The State of World Fisheries and Aquaculture 2018. Meeting the Sustainable Development Goals. Food and Agriculture Organization, Rome.

[4] Cai, J. and Leung, P. (2017) Short-Term Projection of Global Fish Demand and Supply Gaps. FAO Fisheries and Aquaculture Technical Paper No. 607, Food and Agriculture Organization, Rome.

[5] Awuor, F., Obiero, K., Munguti, J., Oginga, J., Kyule, D., Opiyo, M., et al. (2019) Market Linkages and Distribution Channels of Cultured, Captured and Imported Fish in Kenya. Aquaculture Studies, 19, 57-67. https://doi.org/10.4194/2618-6381-v19 106

[6] Tran, N., Chu, L., Chan, C., Genschick, S., Phillips, M. and Kefi, A. (2018) Fish Supply and Demand for Food Security in Sub-Saharan Africa: An Analysis of the Zambian Fish Sector. Marine Policy, 99, 343-350. https://doi.org/10.1016/j.marpol.2018.11.009

[7] AU-IBAR (African Union InterAfrican Bureau for Animal Resources) (2016) Technical Report of the Think Tank Meeting on Sustainable Aquaculture Development in Africa, 7-10 February 2016, Cairo, 120 p. 
[8] KNBS (Kenya National Bureau of Statistics) (2019) Kenya Population and Housing Census. Kenya National Bureau of Statistics, Nairobi.

[9] KNBS (Kenya National Bureau of Statistics) (2018) Economic Survey. Kenya National Bureau of Statistics, Nairobi.

[10] MOA (2020) Ministry of Agriculture. Maintain a Healthy Diet During Covid-19.

[11] KMFRI (Kenya Marine and Fisheries Research Institute) (2017) Kenya's Aquaculture Brief 2017: Status, Trends, Challenges and Future Outlook. Kenya Marine and Fisheries Research Institute, Mombasa, $12 \mathrm{p}$.

[12] Nyaga, J., Nyikal, R. and Busienei, J. (2016) Factors Influencing the Choice of Marketing Channel by Fish Farmers in Kirinyaga County. 2016 5th International Conference, Addis Ababa, 23-26 September 2016, Addis Ababa, Ethiopia 249338, African Association of Agricultural Economists (AAAE).

[13] Meena, M. (2014) The Impact of Farmer to Market Linkages on Livelihoods and Natural Resource Management in Uganda. The Journal of Agricultural Education and Extension, 20, 449-450. https://doi.org/10.1080/1389224X.2014.909198

[14] Mohammed, K.H., Birhane, Z. and Alemayehu, G. (2019) Determinants of Market Outlet Choice Decision of Tomato Producers in Fogera woreda, South Gonder zone, Ethiopia. Cogent Food and Agriculture, 5, Article ID: 1709394. https://doi.org/10.1080/23311932.2019.1709394

[15] Odetola, S., Awoyemi, T. and Ajijola, S. (2015) Impact of Cooperative Society on Fish Farming Commercialization in Lagos State, Nigeria. African Journal of Agricultural Research, 10, 1982-1988. https://doi.org/10.5897/AJAR2015.9609

[16] Kamau, N.J, Margret, W.N. and Hillary, B.K (2018) Structural Analysis of Social Networks Revealed by Small Holder Banana Farmers in Muranga County, Kenya. Journal of Agricultural Science and Food Research, 9, Article No. 221.

[17] Geoffrey, S., Hillary, B.K., Jonah, K.K. and Timothy, O. (2014) Factors Influencing the Choice of Marketing Outlets among Small-Scale Pineapple Farmers in Kericho County, Kenya. International Journal of Regional Developments, 1, 51-56. https://doi.org/10.5296/ijrd.v2i2.6237

[18] Stutzman, E., Molnar, J., Atukunda, G. and Walakira, J. (2017) Understanding the Role of Fish Farmer Associations as Intermediaries for the Commercialization of Aquaculture in Uganda. Fisheries and Aquaculture Journal, 8, Article No. 214. https://doi.org/10.4172/2150-3508.1000214

[19] Hogset, H. and Barrett, C.B. (2010) Social Learning, Social Influence and Projection Bias: A Caution on Inferences Based on Proxy Reporting of Peer Behavior. Economic Development and Cultural Change, 58, 563-589. https://doi.org/10.1086/650424

[20] Muange, E.N., Schwarze, S. and Matin, Q. (2014) Social Networks and Farmer Exposure to Improved Crop Varieties in Tanzania. Global Food Discussion Papers, No. 45. Georg-August-Universität Göttingen, Göttingen.

[21] Serrat, O. (2017) Social Network Analysis. In: Knowledge Solutions, Springer, Singapore, 39-43. https://doi.org/10.1007/978-981-10-0983-9 9

[22] Cote S. and Healy, T. (2001) The Well-Being of Nations: The Role of Human and Social Capital. Organization for Economic Cooperation and Rural Development, Paris.

[23] Ofuoku, A., Emah, G. and Itedjere, B. (2008) Information Utilization among Rural Fish Farmers in Central Agricultural Zone of Delta State, Nigeria. World Journal of Agricultural Sciences, 4, 558-564. 
[24] Kawala, M., Hyuha, T., William, E., Walekwa, P., Elepu, G. and Kalumba, S. (2018) Determinants for Choice of Fish Market Channels: The Case of Busia (Uganda/ Kenya) Border. Journal of Agricultural Science, 10, 118-124. https://doi.org/10.5539/jas.v10n8p118

[25] Turner, R., Polunin, N. and Stead, S. (2014) Social Networks and Fishers' Behavior: Exploring the Links between Information Flow and Fishing Success in the Northumberland Lobster Fishery. Ecology and Society, 19, Article No. 38.

https://doi.org/10.5751/ES-06456-190238

[26] Honja, T., Geta, E. and Mitiku, A. (2017) Determinants of Market Outlet Choice of the Smallholder Mango Producers: The Case of Boloso Bombe Woreda, Wolaita Zone, Southern Ethiopia: A Multivariate Probit Approach. Global Journal of Science Frontier Research: Journal of Agriculture and Veterinary, 17, Issue No. 2.

[27] Greene, W.H. (2003) Econometric Analysis. Prentice-Hall, Upper Saddle River.

[28] Obwanga, B., Rurangwa, E., Duijn, A. and Soma, K. (2018) A Comparative Study of Aquaculture Sector Development in Egypt, Ghana and Nigeria: Insights for Kenya's Sustainable Domestic Sector Development. 3R Research, Kenya.

[29] GOK (2018) Nyeri County Integrated Development Plan 2018-2022.

[30] Kothari, C.R. (2004) Research Methodology. Methods and Techniques. New Age International, New Dheli.

[31] Corsi, A. and Salvioni, C. (2012). Off- and On-Farm Participation in Italian Farm Households. Applied Economics, 44, Issue No. 19. https://doi.org/10.1080/00036846.2011.566181

[32] Louw, A., Vermeulen, H., Kirsten, J. and Madevu, H. (2007) Securing Small Farmer Participation in Supermarket Supply Chains in South Africa. Development Southern Africa, 24, 539-551. https://doi.org/10.1080/03768350701577657

[33] Timothy, O. W. (2006) A Hedonic Analysis of Cattle Prices in the Central Prices in the Central Corridor of West Africa. Implications for Production and Marketing Decisions. Paper Presented at International Association of Agricultural Economists Conference, Gold Coast, 12-18 August, 2006, 1-18.

[34] Sigei, K.G., Bett, K.H., Kiprop, K.J. and Odipo, O.T. (2015) Factors Influencing the Choice of Marketing Outlets among Small-Scale Pineapple Farmers in Kericho County, Kenya. International Journal of Regional Development, 2, 1-11. https://doi.org/10.5296/ijrd.v2i2.6237

[35] Tewodros, T. (2014) Determinants of Smallholder Pulse Producers Market Orientation in Southern Ethiopia. Asian Journal of Business Management, 2, 97-103. https://doi.org/10.19026/ajbm.6.5333

[36] Wosene, G., Ketema, M. and Ademe, A. (2018) Factors Affecting Market Outlet Choices of Pepper Producers in Wonberma District, Northwest Ethiopia: Multivariate Probit Approach. Cogent Food \& Agriculture, 4, Article ID: 1558497. https://doi.org/10.1080/23311932.2018.1558497

[37] Abate, T., Mekie, T. and Dessie, A. (2019) Determinants of Market Outlet Choices by Smallholder Teff Farmers in Dera District, South Gondar Zone, Amhara National Regional State, Ethiopia: A Multivariate Probit Approach. Journal of Economic Structures, 8, Article No. 39. https://doi.org/10.1186/s40008-019-0167-x

[38] Mburu, L.M., Wakhungu, J.W. and Gitu, K.W. (2007) Determinants of Smallholder Dairy Farmers' Adoption of Various Milk Marketing Channels in Kenya Highlands. Livestock Research for Rural Development, 19, 1-20.

[39] Tarekegn, K., Haji, J. and Tegegne, B. (2017) Determinants of Honey Producer Mar- 
ket Outlet Choice in Chena District, Southern Ethiopia: A Multivariate Probit Regression Analysis. Agricultural and Food Economics, 5, Article No. 20.

https://doi.org/10.1186/s40100-017-0090-0

[40] Mmbando, F., Wale, E., Baiyegunhi, L. and Darroch, M. (2016) The Choice of MarketingChannel by Maize and Pigeonpea Smallholder Farmers: Evidence from the Northern and Eastern Zones of Tanzania. Agrekon, 55, 254-277.

https://doi.org/10.1080/03031853.2016.1203803

[41] Jari, B. and Fraser, C.G, (2009) An Analysis of Institutional and Technical Factors Influencing Agricultural Marketing amongst Smallholder Farmers in the Kat River valley, Eastern Cape, South Africa. African Journal of Agricultural Research, 4, 11291137. 